\title{
Bandwagon heads east
}

\section{Tokyo}

JAPAN's Environment Agency, which has recently been talking tough (and getting its way) on everything from the protection of the ozone layer to the preservation of Okinawa's coral reefs, is calling on Japan to play a bigger role in protecting the global environment in two reports released last week.

The newly formed Global Environment Protection Bureau, made up of senior agency officials, urges the government and the private sector to contribute more to global environmental protection, particularly in developing countries of the neighbouring Asia-Pacific region. The report came a day after the release of the agency's annual white paper (see below) which also stresses the need for Japan to

\section{JAPANESE ENVIRONMENT}

\section{Midsummer days and tropical nights in Tokyo}

\section{Tokyo}

TOKYO residents are already sweltering under the effects of man-induced climate change, according to the Environment Agency's latest white paper released last week.

The white paper, subtitled "Toward Ecopolis - the city where man lives in harmony with the environment", shows that the number of "midsummer days" (days when the temperature exceeds $30{ }^{\circ} \mathrm{C}$ ) and "tropical nights" (nights when the temperature fails to drop below $25^{\circ} \mathrm{C}$ ) in Tokyo is soaring. Tropical nights are ten times as frequent as a century ago.

The agency says summer temperatures are rising because of heat generated by cars, machines and electrical appliances and radiation reflected from buildings and roads. Ironically, the 'heat-island effect' is greatest at night during Tokyo's hot muggy summers when sunlight is strong and residents switch on their air conditioners.

Coolers should simply suck heat out of the room and pump it outside the home without adding heat. But even the best coolers are only about 30 per cent efficient, says Hisakazu Kato, a division director of the Environment Agency, and they give off a lot of excess heat.

Traditional wooden homes simply relied on summer breezes to keep occupants cool. But Tokyo is fast turning into a city of concrete apartments, each with its own air conditioning. The white paper calls for centralized district heating and cooling systems to help a return to an "ecologically oriented urban infrastructure".

David Swinbanks participate actively in international efforts to protect the world's environment.

To promote more research, the bureau calls for monitoring of the ozone layer, rain-forest destruction, acid rain and marine pollution in Japan and the AsiaPacific region using satellites, ships, aircraft and laser radar. It also recommends the establishment of inter-agency research involving different government ministries (not easy in Japan) and urges active participation in the UN Environment Program (UNEP), the Intergovernmental Panel on Climate Change (IPCC) and international research efforts such as the International Geosphere-Biosphere Program (IGBP).

To help developing countries, the report calls for increased overseas development aid for projects related to the environment and the design of energysaving technologies and environmental monitoring and protection systems suited to their special needs. The agency also offers to draw up stricter environmental guidelines for Japanese private industries investing overseas.

Finally, the report urges the government to develop a 'global green strategy' to minimize tropical forest destruction, desertification and loss of biodiversity in the world. Among the measures called for are greater support of the International Tropical Timber Organization (ITTO) and its efforts to promote sustainable forest management, Japanese help in establishing national parks and preserves in developing countries and education to raise the Japanese public's consciousness of environmental issues, including the introduction of 'ecomark' labels for products that have little adverse effect on the environment. The report also says its time for Japan to "come to grips" with the need to protect wildlife in developing countries. Japan has been severely criticized for its role in the destruction of tropical rainforests and for permitting trade in endangered wildlife.

Despite international censure, Japan has made important contributions to protection of the global environment, according to Hisakazu Kato of the Environment Agency. Japan reacted swiftly to the oil crisis of the 1970 s and through efficient use of energy produces far less carbon dioxide per head from the burning of fossil fuels than does the United States.

International concern over the global environment has strengthened the Environment Agency's own political clout. The proposals in the agency's reports will most probably set Japanese policy at the summit meeting of the advanced nations in Paris later this year. The global environment will be a key issue.

David Swinbanks

\section{Hubble telescope faces further delay}

\section{Washington}

The National Aeronautics and Space Administration (NASA) continues to shuffle its shuttle launch schedule, and for astronomers this means another delay albeit a slight one - for the Hubble Space Telescope.

With Magellan on its way to Venus after a successful launch aboard the space shuttle Atlantis, NASA officials are upbeat about what promises to be an exciting year for space science.

But they are also being cautious, in order. to "protect" two planetary missions that have critical launch windows. Only one of two planned Department of Defense missions will now go ahead before the scheduled 12 October launch of the Galileo mission to Jupiter. The Hubble Space Telescope will be launched after just three intervening missions: two military missions, and a mission to deploy a communications satellite. The space telescope launch is now unlikely to occur before February 1990.

Other science missions scheduled for launch on the shuttle in the next 18 months or so include Astro 1, a series of onboard astrophysics experiments, the GammaRay Observatory, a companion to the Hubble Space Telescope in the great observatories series, and Ulysses, the joint mission with the European Space Agency to explore the Sun's poles.

COBE, the Cosmic Background Explorer, originally scheduled for a June launch on a Delta expendable launch vehicle, has now been delayed until November.

Joseph Palca

\section{GENOME MAPPING}

\section{Support ends at Yale for mapping library}

\section{Washington}

THE Howard Hughes Medical Institute plans to end its support of the Human Gene Mapping Library at Yale University in August 1990 in the expectation that funds will be provided by the federal genome project. Since 1985, the institute has contributed \$1 million a year to the operation of databases at Yale containing the current human genetic map, restriction fragment length polymorphisms, genetic probes, lists of investigators studying human genetics, and literature citations on human genetic disease.

The institute has hired Peter Pearson from the University of Leiden in the Netherlands to devise a new generation relational database drawing upon the Yale library headed by Frank Ruddle, and another database on human genetics run $b$, Victor McKusick of Johns Hopkins University.

Carol Ezzell 